\title{
Research on Property Rights System of China's Rural Land Based on Community Governance
}

\author{
Xuechuan Li \\ Sichuan Agricultural University, Chengdu, 611130, China
}

Keywords: Property Rights system, Rural land, Community governance

\begin{abstract}
At present, our country is under the background of building a new socialist countryside, and the issue of rural land property rights is a hot topic in our theoretical circles. Community governance is closely related to China's rural land property rights system. In the early stage of reform and opening-up, the system of household contract responsibility for land based on the co-governance of government and the people has injected vitality into agricultural production. In the new era, it put forward proposals for the reform of China's rural land property rights system based on community governance to provide some references for the relevant researchers.
\end{abstract}

\section{Introduction}

Community governance refers to the process and mechanism of government, community organizations, residents and district units, profit-making organizations and non-profit organizations based on market principles, public interests and community identity, coordinating and cooperating, effectively supplying community public goods, meeting community needs and optimizing community order [1]. In addition, community governance is the practical application of governance theory in the community field. It refers to the governance of public affairs within the community. As the microcosmic foundation of society, rural community has important significance in promoting social harmonious development and maintaining social stability, and has always been widely concerned by scholars at home and abroad. Rural communities in China have undergone a historical process of development and evolution. The forms and structures of rural communities in different periods show great differences, and the governance of rural communities has obvious differences. Rural community governance in different periods is affected by different factors and has different governance logic, which challenges the research of rural community governance. At the critical stage of rural community construction, rural communities, as a micro-governance unit in grass-roots governance, show great differences in the process of rapid industrialization, marketization and urbanization. How to build an appropriate governance mechanism in the development of modern society can not only meet the practical needs of national governance. It is worth thinking deeply that we can effectively safeguard the basic rights and interests of the people and form a win-win situation of grass-roots community governance. In addition, rural community governance is a historic process of change. The development and change of rural community are inherent in the changes of economic and social development. The system is also an important norm for standardizing community behavior and development. Rural community governance is an institutional arrangement, which will change and evolve with the development of rural society [2].

\section{Property Rights of Rural Land and Community Governance}

\subsection{Rural Self-government and Traditional Land Property Rights.}

The birthplace of Chinese civilization in inland plains is relatively suitable for farming. Land is the most important resource of agricultural production, and the rural area is the most important space carrier of agricultural society. With the promotion and use of ironware, a family-by-family peasant 
has formed a long-term use relationship with a small plot of land, and many members of the village community have become individual peasants in a single household. The basic economic structure of the whole Chinese society is still a small land ownership system based on agricultural production. The individual family management on this small piece of land is the economic cell of the whole society. At the same time, the surplus provided by small-scale production is always limited, so the unrestricted imperial power cannot penetrate its power into the bottom of society because of lack of financial resources, but can only stop at the county. The administrative tasks of the state are mainly taxation and requisitioned labor. In order to survive and multiply for a long time, small farmers living in kinship, kinship and geographical relationship form a small community, relying on the strength of the community to solve production problems. Autocratic monarchy abandoned many of its obligations to the people, and had to give up the power of control. Civil private and civil management in grass-roots society means that grass-roots society relies on internal self-management to maintain its survival and development, which is rural autonomy. Traditional China is actually divided into upper-class state and grass-roots society, and dynasties and regimes are constantly changing at the upper levels of the country. On the contrary, in the lower society, people live a quiet life of sunrise and sunset, and the two societies are isolated. Under the rule of the state, the rural society in China has a high degree of autonomy. This is determined by the small peasant economy under the traditional land ownership system [3].

\subsection{Collective Land Ownership and Bureaucratic Domination.}

With the sharp conflict between the small-scale production of each household and the goal of industrialization to be achieved by the state, another land system reform has begun. In the historical scene at that time, in order to realize industrialization, the state first concentrated more agricultural surplus into its own hands, so from mutual aid groups to cooperatives and then to people's communes, land quickly changed from private ownership to collective ownership. State control is unprecedented in rural society. The carrier of state control of rural society is the people's commune established in the vast rural areas. The people's commune is not only an economic unit, but also a grass-roots political unit, that is, the state controls and governs rural society through the people's commune. The people's commune is an organization that combines politics with society. Peasants lose their living resources when they leave the commune. At the same time, peasants gain common membership, not only as producers, but also as members of the regime organizational system, and therefore have national identity. Commune is an all-embracing organizational system, which includes the functions of organizing production, propaganda and education, social service and so on, besides the function of political domination. The construction process of the commune system is also a process of expanding the functions of state political power and political power. Therefore, under the commune system, the power concentration and infiltration ability of the regime organizations have reached an unprecedented level. The state finally integrates the discrete local society into the regime system through the regime going to the countryside, and the state controls the society. After the land reform, the grass-roots organizations of the Party were generally established in rural society. At the same time, mass organizations such as the Communist Youth League, the Women's Federation, the militia and the agricultural association were established around the Party organizations. Most of the masses became members of these organizations. Through the Party's organization, the peasants, who had been scattered in history and had always been outside the political system, were transformed into organized political forces, and made them the basis for the stability of the regime. The process of political party organization infiltrating into the countryside, integrating and politicized the rural society. The Communist Party of China extends its leadership system to rural society and systematically communicates the relationship between the Party and the state and farmers [4].

\subsection{Household Contract of Land and Official and People Co-Government.}

With the completion of the household contract system in a relatively short period of time throughout the country, land property rights have changed from a single subject and a single right structure to two levels of subjects and separable rights bundles. The ultimate ownership of land 
belongs to the community collective, but the right of management, part of the right of income and the right of possession of surplus products return to farmers and individuals. But the contracting system is to divide the land equally according to the population, and the land adjustment with the population increasing and decreasing makes the land more and more fragmented. The scale of production of farmers is still very small. The small-scale production of each household will still face difficulties in production and life. At this time, after the political movements after the founding of the People's Republic, the traditional ties of blood, family and clan are affected. To the fierce impact, the original self-organization and mutual aid system of the rural community has disappeared. At the same time, the disintegration of the people's commune left a vacuum for governance in rural society. More importantly, self-management gives farmers the status of economic subject. With the emergence of this new economic relationship, farmers have more autonomy and freedom of choice in production and life. As economic subject, they should safeguard their own interests, care about matters related to their own interests, and demand knowledge of community affairs. The right of emotion, the right of recommendation, and even the right to participate in decision-making. On the one hand, the need to strongly safeguard the interests of economic subjects and the requirements of community affairs management, on the other hand, the disintegration of the system of communes and production teams, so farmers spontaneously formed a conference to manage their own affairs in the vast rural areas. With the township government becoming a grass-roots regime. This is not only the creative transformation of rural social governance model, but also fundamentally changes the relationship between the state and society. The state has built the grass-roots political power in the township government, and implemented villagers' autonomy below the township level. Farmers have a platform to manage village community affairs and safeguard their own interests, and implement self-management in certain areas. But unlike the history of rural autonomy, the Party and the government still play a leading role in rural governance, forming a pattern of government-people co-governance.

\section{Reform Suggestions of Property Rights System of China's Rural Land Based on Community Governance}

\subsection{Clarify Rights of Subject.}

The main body of farmland ownership in China is ambiguous, so it is difficult to define the sole subject of unified farmland ownership in law in practice, and it may cause confusion among the main body of farmland ownership. Therefore, instead of dwelling on the issue of the sole subject of farmland ownership, we should put it aside temporarily and limit the rights and obligations of the subject of farmland ownership through laws, regulations and necessary administrative means, so as to reduce the unreasonable interference and infringement of the subject of ownership on farmland production and operation activities. More conducive to ensuring the legitimate rights and interests of farmers. To clarify the rights and obligations of rural land owners is to clarify the rights and obligations of peasant collectives as land owners. Here, we first classify peasant collective as the right of land owners into five items. No matter how the right of use changes, the collective ownership of rural land belongs to the collective ownership of rural farmers in law. Ownership subjects have the right to distribute and contract their land, but when contracting or leasing to units and individuals other than collective members, they must obtain the consent of collective members of farmers in villages, and have the right to resist illegal land expropriation by non-public utilities, reflecting the owner's right of control. Ownership subjects have the right to manage and manage land assets, including the requirements for users to fertilize the soil, improve the soil and protect the environment, so as to maintain or increase the value of land assets. Ownership subjects have the right to supervise users to make long-term land use plans according to law without changing the use of land. The owner may extract the proceeds from his land according to law. In addition, the land owner has the right to transfer the actual possession, use, income distribution and part of the disposal right to the land user. 


\subsection{Construct Mechanism of Circulation.}

The main body of the right to use rural land is farmers, so the main body of the transfer of usufruct should also be farmers. The transfer of land should be decided by the farmers themselves, and we should adhere to the diversified forms of land circulation and adjust measures to local conditions. Whatever form of transfer is adopted, it must be based on household contract, and it must follow the principles of law, voluntariness and compensation. In accordance with the law, it is to standardize the circulation according to the principles and procedures stipulated in the land contract law. Voluntary means that the land contractor has the right to decide whether or not the contracted land is to be transferred and in what form. No organization or individual may force the contractor to transfer the land. Land is not only the means of production but also the means of livelihood of farmers. Therefore, the transfer of land contractual management rights should be paid. No organization or individual may withhold or withhold the income without authorization, and all of it belongs to the contractor. Gradually improve the price formation mechanism of land transfer, reasonable land price is the necessary prerequisite for the operation of rural land market. The marketization of the transfer of land use right requires that land assets follow the market rules and make the land use right flow freely and allocate optimally among different subjects through the competitive mechanism of eliminating the fittest and eliminating the fittest. At present, the low price of rural land transfer has hindered the smooth operation of land circulation. Therefore, improving the price mechanism is the inevitable requirement to realize the marketization of land circulation. Establishing a standardized intermediary mechanism for land transfer. Land use right transaction is a relatively complex transaction process, because it involves all parties involved in the transaction, it needs corresponding intermediary organizations to serve it. The intermediary services in rural areas are basically played by collective economic organizations. Collective economic organizations, as intermediary organizations, because of their small scope of social activities and limited coverage, lead to high operating costs and low efficiency, which are not conducive to the development of the land market and the two-way choice of the transaction subjects. In addition, collective economic organizations inevitably interfere in the process of acting as intermediaries and need to establish independence from the collective and land. The intermediary agencies outside the user establish a standardized land intermediary mechanism.

\subsection{Perfect Security System.}

The minimum living security system is an important part of the social security system. It refers to the people whose living standards are temporarily or permanently lower than the minimum living security level promulgated by the state. The minimum subsistence security system is a social assistance system to solve the problem of poverty. It guarantees all citizens of a country. At present, the objects of protection are not all landless peasants, but those whose basic life is not guaranteed. Most of them are older and weaker landless peasants. Generally speaking, they include low-income families who lack labor force, families who are poor because of disasters, serious diseases and disabilities, and those who are incapable of working. This part of the land-lost peasants is the basic livelihood security that the government needs to provide for the elderly, minors and disabled people who have no source of livelihood and cannot fix their dependents. As long as the conditions are met, the landless peasants cannot be excluded from receiving high compensation fees for land expropriation. In determining the minimum living standard, a more scientific standard should be determined according to the basic living needs, government financial resources, social affordability and other factors. Because of the differences in the economic development of different regions, the minimum living standards of different regions can be different. We must have a stable fund-raising mechanism and strict management mechanism. The government can take indirect financial subsidies, or issue special bonds, lotteries, tax transfers, etc. At the same time, corporate finance, business insurance and social sponsorship can also be used to raise funds. We have formulated a series of management systems that are scientifically rigorous and easy to operate and accept the supervision of the masses. 


\section{Conclusion}

With the deepening of reform, the reform of market economy ultimately rests on the property right system. As an important aspect of the property right system, the land property right system has gradually become the core of the land problem. Based on community governance, we can construct an efficient land property rights system, which will benefit the vast number of farmers in China, and then contribute to China's economic and social development.

\section{References}

[1] Huang Zengjian, Tang Juanli, Huang Baolian. Study on paid exit platform and operation mechanism of farmers' land from the perspective of modern property rights [J]. Journal of Shanxi Agricultural University (Social Science Edition), 2018, 17(2): 38-43.

[2] Huang Jinsheng, Chen Ligen. An Institutional Equilibrium Analysison Land Property Rights System and Regulation System [J]. Journal of Nanjing Agricultural University (Social Sciences Edition), 2016, 16(1): 82-91+164-165.

[3] Zhang Yingliang, Yang Fang. Practical Examples and Theoretical Logic of Rural Collective Property Rights System Reform [J]. Reform, 2017(3): 119-129.

[4] Cheng Chunli. The Realistic Demand and Path Selection of the Rural Collective Property Rights System [J]. Economic Research Guide, 2018(25): 7-9+26. 